<シンポジウム 10 - $2>$ 神経機能画像の進歩

\title{
PET をもちいた脳ミクログリアの画像化
}

\author{
尾内 康臣
}

\begin{abstract}
要旨 : ミクログリアは脳実質内グリア細胞の $10 \%$ を占め, 安静時では ramified 型をして繊毛突起を出して絶え ず移動して免疫監視作用にかかわっている. ところが, 脳組織が傷害を受けると傷害された神経細胞やアストロサ イトからの刺激によって ameboid 型と形を变え, ミクログリアが傷害側まで誘導される. 血管障害や変性疾患など の神経疾患だけでなく, 直接的な脳病理学的所見が不明確とされる精神疾患においても, 神経細胞やアストロサイ トの異常によってミクログリア活性が上昇していることが最近報告されている. 活性化ミクログリアはグルタミン 酸神経シナプスなどを剝離して異常興奮を抑制する神経保護に関与する一方, 咨症性サイトカインを放出し細胞傷 害を若起する. すなわちミクログリアの活性化こそ脳内での炎症の存在を示す証拠となる．この神経炎症を死後脳 でなく，生きた脳で捉えることは疾患の病態を評価し，治療方針の決定に重要となる．活性化したミクログリアに は, 末梢性ベンゾジアゼピン受容体が多数発現し，その受容体に結合するトレーサーとPET を使うことで可視化で きる. 様々なトレーサー開発がおこなわれているが，中でも $\left.{ }^{11} \mathrm{C}\right](\mathrm{R})-\mathrm{PK} 11195$ は感度は低いが世界で広く臨床利 用されている PET トレーサーである. このトレーサーは傷害性ミクログリアと保護的ミクログリア(果たして末梢 性ベンゾジアゼピン受容体の差で差別化できるか疑問であるが) の区別なく，活性化したミクログリアを検出する ことができる. 本シンポジウムでは神経・精神疾患の患者脳におけるミクログリア活性について述べる.
\end{abstract}

(臨床神経，49：925一928, 2009）

Key words : 神経炎症，ミクログリア，脳変性疾患，ポジトロン断層撮影， $\left[{ }^{[1} \mathrm{C}\right](\mathrm{R})-\mathrm{PK} 11195$

\section{はじめに}

脳内の分子異常をひきおこすものの一つに炎症がある．炎 症とは外傷, 細菌の進入, 薬物, 放射線などの作用に対する生 体の防御反応で，組織保護と組織障害の 2 面性をともなう現 象である．脳実質内でこの防御反応を担うのは主にミクログ リアであり,その起源は, 胎児期 4 日に前駆細胞として出現す るといわれている。これらの細胞膜上に MHC 抗原（Major histocompatibility comple）が発現され，領食性を有するよう になり，種々のサイトカイン(IL-1，IL- 6, TNF- $\alpha$, IFN- $\gamma$ )や iNOS などの炎症性化学物質が産生される。これらの化学物 質は炎症組織のみならず，周囲の変性領域に作用し細胞障害 を生じさせる.たとえばアルッハイマー病では, 老人斑の周囲 にはサイトカインが多く産生され，アミロイド前駆体蛋白を 刺激して，アミロイド $\beta$ 蛋白の産生をうながす。 アミロイド $\beta$ 蛋白はミクログリアなどから TNF- $\alpha$ や NO などの炎症性 物質の産生をうながし, 細胞障害が連続する.脳の変性疾患で は, 脳血管関門が破綻し細胞外免疫組織が流入して炎症をお こす脳炎や血管障害などとことなり，ミクログリアとアスト ロサイトが重要な免疫応答細胞として機能している。本稿で は, PETをもちいて生きている脳内でのミクログリアの画像 化について記述する.

\section{ミクログリアは静止していない}

ミクログリアは脳実質内グリア細胞の $10 \%$ を占める ${ }^{1)}$ とさ れ，その起源は胎児期の脳血管関門が不完全な時期に脳内に 進入してミクログリアと分化したものとされる．初期には未 成熟な非 ramified 型をして神経細胞の淘汰に関与している と推測され，しだいに ramified 型をした静止ミクログリアに なると考えられている. 静止ミクログリアは正常組織の回り に瀻毛突起を出して絶えず移動して免疫監視作用にかかわっ ているとされる。一旦, 脳組織が障害を受けると障害された神 経細胞やアストロサイトから ATPが放出されて, ミクログ リアが障害側まで誘導される。 ミクログリアを静止させるも のとして，神経細胞膜上の糖タンパクである CD200 がある が，ミクログリア上にある CD200 の受容体を介する作用 ${ }^{2)} に$ よって，あるいは神経細胞の電気的活動によってミクログリ アを静止状態に保っている3)とされる.ささらにアストロサイト が TGF- $\beta$ を放出してミクログリアの活性化を抑制している4) ことも指摘されている.このようにミクログリアは神経細胞 とアストロサイトによってその活性がコントロールされてい て, 脳組織の損傷に対してすぐに反応できるように臨戦態勢 にあるともいえる。

国立大学法人浜松医科大学分子イメージング先端研究センターヒトイメージング研究部門〔テ431-3192 静岡県浜松市東区半田山 1一 20-1]

(受付日：2009 年 5 月 22 日) 


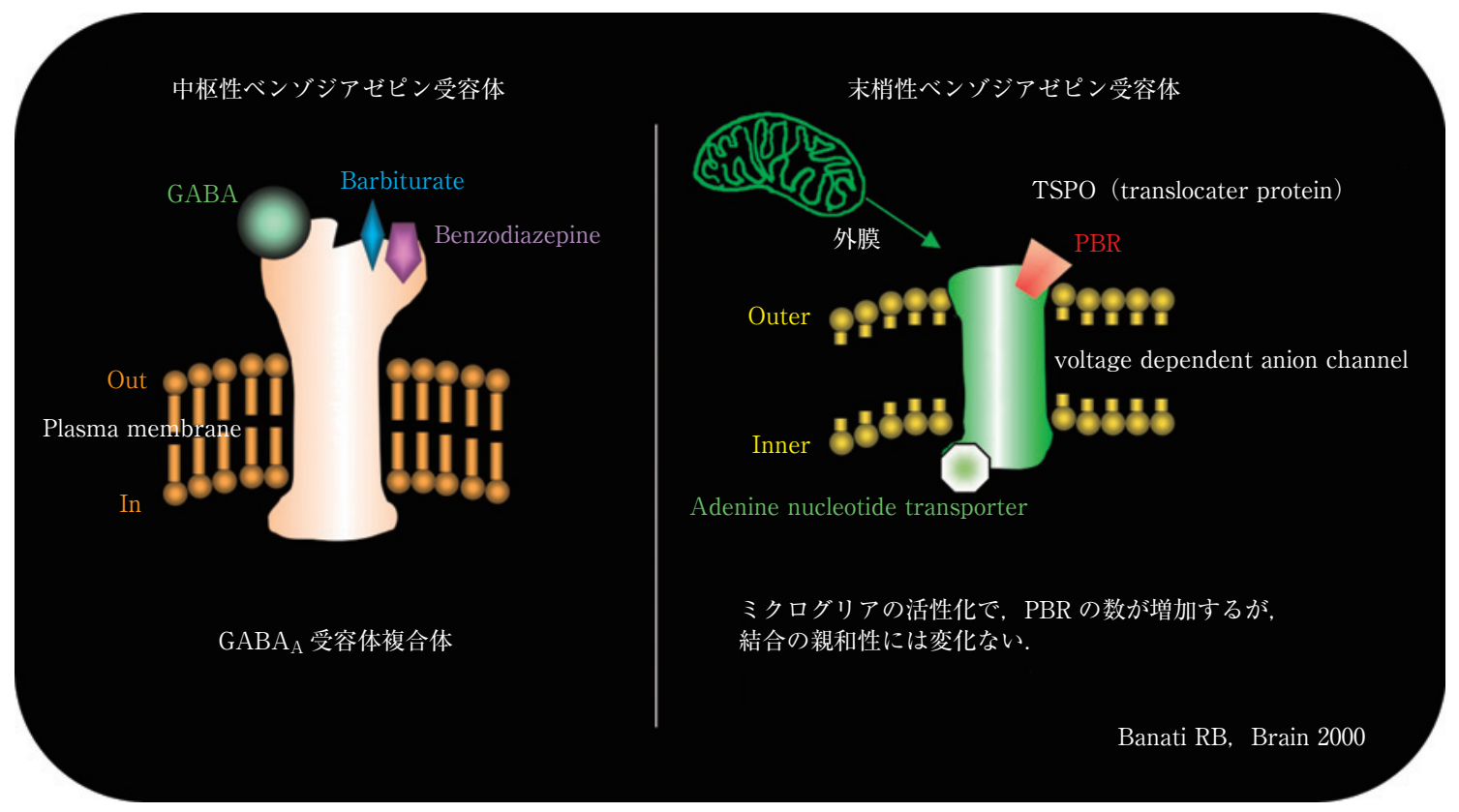

Fig. 1 中枢性と末梢性ベンゾジアゼピン受容体の模式図

\section{ミクログリアが活性化する}

ミクログリアの活性化には，上記したように実際に脳実質 が損傷し，損傷組織に移動しサイトカインなどの放出に関与 する過程と，神経連絡が断絶され遠位にある神経細胞が物理 的な障害を受けた時に生じるものがある，後者の例は顔面神 経や腰髄を切断したラット脳の神経核周辺での反応がそうで ある.このばあいは, 活性化ミクログリアは神経核周囲に集簇 し，グルタミン酸神経シナプスなどを剝離して異常興奮を抑 制する神経保護に関与している。 ミクログリアの抗原提示に 関しては MCH-class II 分子が重要で, 様々な化学物質とくに INF- $\gamma$ は強力に活性化する。活性化された MCH-II や CD40 などは T cell 増殖をうながしたり, IL-2 や INF- $\gamma$ の産生を助 長する。この MCH-II 分子活性を抑制するものとして, PGE2, IL-10 や TGF- $\beta 1$ などが知られている.

ミクログリアを活性化する物質として，グラム㓌性大腸菌 細胞膜のエンドトキシンである LPS, 活性 Th1 や NK 細胞か ら放出される INF- $\gamma$, 小分子のケモカイン, $45 \mathrm{kDa}$ の膜通過蛋 白である CD40, アミロイド $\beta$ 蛋白， $\alpha$ シヌクレイン，シアル 酸含有の glycosphingolipid であるガングリオシドやプロト ロンビンから生成されるトロンビンなどが報告されている.

\section{活性化ミクログリアの PET 研究}

ミクログリアが活性化されるとミトコンドリア外膜に位置

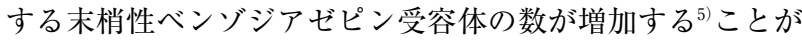
示され (Fig. 1)，そのトレーサーである $\left[{ }^{11} \mathrm{C}\right](R)-\mathrm{PK} 11195$ を使うことで positron emission tomography (PET) で in vivo
でのミクログリア活性をしらべられることが報告された．

$\left[{ }^{11} \mathrm{C}\right](R)-\mathrm{PK} 11195$ を使ってこれまでに様々な脳疾患でイ メージングされ報告されている。 その例を年代毎に列挙する と, 1999 年 Rasmussen’s encephalitis (Banati, Neurology), 2000 年 Ischemic stroke（Gerhard, Neuroreport)，2000 年 Multiple sclerosis (Banati, Brain), 2001 年 Alzheimer's disease (Cagnin, Banati, Lancet), 2004 年 ALS (Turner, Banati, Neurobiol Dis), 2004 年 Corticobasal degeneration (Henkel, Mov Disord), 2004 年 Frontotemporal dementia (Cagnin, Banati, Ann Neurol), 2005 年 Parkinson's disease (Ouchi, Ann Neurol)， 2006 年 Huntington's disease (Pavese, Neurology), 2008 年 Methamphetamine abuser (Sekine, Ouchi, J Neurosci), 2008 年 Schizophrenia（van Berckel, Biol Psychiatry) となる.われわれは以前このト レーサーを応用して，中脳における $\left[{ }^{11} \mathrm{C}\right](R)-\mathrm{PK} 11195$ の結合 能が上昇していることを未治療の初期パーキンソン病患者で 上昇していることを示した (Fig. 2 上段).

節前性ドパミン神経を評価できる $\left[{ }^{11} \mathrm{C}\right] \beta-\mathrm{CFT}$ というト レーサーを併用すると，中脳の $\left[{ }^{11} \mathrm{C}\right](R)-\mathrm{PK} 11195$ 結合能は $\left[{ }^{11} \mathrm{C}\right] \beta-\mathrm{CFT}$ 結合と逆相関を示した ${ }^{6)}$ が，このことはドパミン 神経細胞の障害が強いほどミクログリア活性が上昇すること を示唆している.

さらに覚醒剂使用者の脳内でのミクログリア活性をしらべ ると明らかに全脳で上昇していた ${ }^{7)}$.このミクログリア活性の 上昇 $\left(\left[{ }^{11} \mathrm{C}\right](R)-\mathrm{PK} 11195\right.$ 結合能) は薬物の使用中断期間が長 いほど低下することがわかり，使用を中止すれば脳内炎症が 低下することが示唆された。

これまでの PET 研究からこのミクログリア活性が炎症性 か抗炎症性かに働いているかは不明（おそらく両方向の作用 


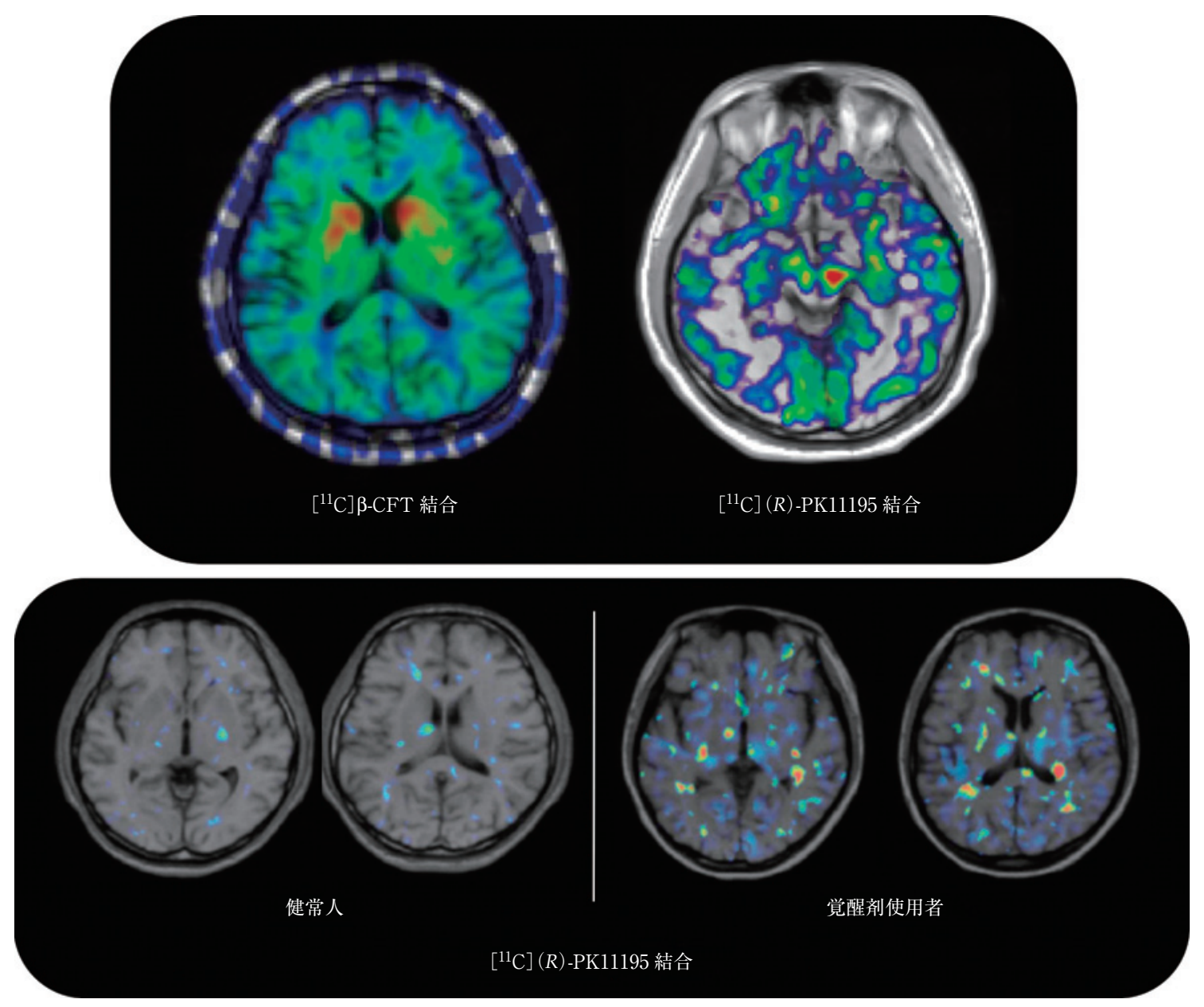

Fig. 2 パーキンソン病（上段）と覚醒剤（下段）

をしていると考えられる)だが, 少なくてもこの活性化を静め ることは治療上有効と考えるため, 治療効果判定や経時的変 化の描出にPET 研究の意義は大きい.アルツハイマー病患 者のアミロイドイメージングが in vivo で可能となり, もし $\alpha$-synuclein の画像化も実現できれば, 2 大脳変性疾患におけ る活性化ミクログリアの発現と病因物質との関係をしらべる ことができ，実験動物では困難なヒト脳での知見がえられる だろう。

\section{おわりに}

脳変性疾患における脳の炎症を考えるとき，その細胞死に ともなう脳組織障害と修復におけるグリア細胞の役割やメカ ニズムを知ることは重要である．炎症の中心的働きをするミ クログリアの働きに着目してイメージングすることは病気の 本体を解明する一助となり, 治療効果のモニタリングという 客観的マーカーとなりえると期待される．今後はミクログリ アの神経保護と神経傷害の二つの側面を画像化できるトレー サーが望まれ，ますます分子イメージング手法のヒトでの応 用は重要なものとなる.
謝辞: 本研究の成果は浜松医大精神神経科, 浜松ホトニクス中 央研究所および浜松医療センターの各研究者の協力の賜物であ り,この場をお借りして深謝いたします.

\section{文献}

1) Perry VH: A revised view of the central nervous system microenvironment and major histocompatibility complex class II antigen presentation. J Neuroimmunol 1998; 90: $113-121$

2) Hoek RM, Ruuls SR, Murphy CA, et al: Down-regulation of the macrophage lineage through interaction with OX2 (CD200). Science 2000; 290: 1768-1771

3) Neumann $\mathrm{H}$ : Control of glial immune function by neurons. Glia 2001; 36: 191-199

4) Vincent VA, Tilders FJ, Van Dam AM: Inhibition of endotoxin-induced nitric oxide synthase production in microglial cells by the presence of astroglial cells: a role for transforming growth factor beta. Glia 1997; 19: 190-198

5) Banati RB, Newcombe J, Gunn RN, et al: The peripheral benzodiazepine binding site in the brain in multiple scle- 
rosis: quantitative in vivo imaging of microglia as a measure of disease activity. Brain 2000; 123: 2321-2337

6) Ouchi Y, Yoshikawa E, Sekine Y, et al: Microglial activation and dopamine terminal loss in early Parkinson's dis- ease. Ann Neurol 2005; 57: 168—175

7) Sekine Y, Ouchi Y, Sugihara G, et al: Methamphetamine causes microglial activation in the brains of human abusers. J Neurosci 2008; 28: 5756-5761

\section{Abstract}

\section{Imaging of brain microgliosis by PET}

Yasuomi Ouchi, M.D.

Human Brain Imaging Research Laboratory, Molecular Imaging Frontier Research Center, Hamamatsu University, School of Medicine

Microglia in the brain are no longer quiescent but active by extending their dendrite and villi to their vicinity, so that microglia play roles in immune surveillance in a similar way as macrophages in the periphery. Changing their shapes from ramified to ameboid forms is a sign of neuroinflammation triggered by damaged neurons or astrocytes. This microgliosis is caused not only by direct brain injury or vascular damage but neurodegeneration, the latter of which was first shown in Alzheimer's disease in vivo by PET with widely-used peripheral benzodiazepine receptor $(\mathrm{PBR})$ tracer $\left[{ }^{11} \mathrm{C}\right](\mathrm{R})-\mathrm{PK} 11195$. The number of the PRB is reportedly increased on the surface of mitochondrial adventitia of the activated microglia, but the affinity to the tracer is shown stable. Using this tracer is advantageous to depict the level of neuroinflammation in vivo in many neurodegenerative diseases. However, the weak point of the tracer is no capacity to differentiate protective microglia from proinflammatory ones. So, a new tracer with its segregation capacity would be expected to come in the near future. This talk is going to cover the application of the PBR tracer to image the neuroinflammation in vivo in neurological and psychiatric diseases.

(Clin Neurol, 49: 925—928, 2009)

Key words: neuroinflammation, microglia, neurodegeneration, positron emission tomography, $\left.{ }^{11} \mathrm{C}\right](\mathrm{R})-\mathrm{PK} 11195$ 